\title{
DECOLONIZANDO A SEXUALIDADE NO ISLÃ: UM DIÁLOGO COM MULHERES MUÇULMANAS BRASILEIRAS
}

\author{
DECOLONIZANDO LA SEXUALIDAD EN EL ISLAM: \\ UN DIÁLOGO CON MUJERES MUSULMANAS BRASILEÑAS
}

\author{
DECOLONIZING SEXUALITY IN ISLAM: \\ A DIALOGUE WITH BRAZILIAN MUSLIM WOMEN
}

\author{
Camila Motta Paiva $^{1}$ e Francirosy Campos Barbosa ${ }^{1}$
}

${ }^{1}$ Universidade de São Paulo, Ribeirão Preto/SP, Brasil

\begin{abstract}
RESUMO: Os estudos de gênero e sexualidade vêm se destacando nas pautas atuais de pesquisas realizadas em campo islâmico. Existe dentro da religião um incentivo aos prazeres que contraria a visão estereotipada da opressão e repressão da mulher muçulmana, bem como a relação problemática entre feminismo e religião que muitas acadêmicas e militantes muçulmanas vêm tentando desconstruir. A partir da etnografia realizada pelas autoras, são tecidas reflexões sobre a sexualidade no Islã a partir de uma perspectiva decolonial. Busca-se ressaltar as práticas e os sentidos que as mulheres muçulmanas brasileiras revertidas ao Islã atribuem à sexualidade, dentro dos seguintes eixos: (a) vestimenta islâmica e a fetichização da muçulmana; (b) lícito/ilícito e a capacidade de agência e protagonismo dessas mulheres; (c) conhecimento religioso e empoderamento feminino. A pesquisa permite destacar dimensões das experiências das mulheres muçulmanas que diferem da posição de subalternidade a qual são constantemente submetidas.
\end{abstract}

PALAVRAS-CHAVE: Sexualidade; Mulheres muçulmanas; Decolonialidade; Islã no Brasil.

RESUMEN: Los estudios de género y sexualidad se han destacado en la actual agenda de investigación llevada a cabo en el campo islámico. Dentro de la religión existe un incentivo al placer que va en contra la visión estereotipada de la opresión y represión de las mujeres musulmanas, así como de la relación problemática entre el feminismo y la religión que muchas académicas y militantes musulmanas están intentando deconstruir. A partir de la etnografía realizada por las autoras, las reflexiones sobre la sexualidad en el Islam se realizan desde una perspectiva decolonial. El artículo busca resaltar las prácticas y los significados que las mujeres musulmanas brasileñas que volvieron al Islam atribuyen a la sexualidad, dentro de los siguientes ejes: (a) vestimenta islámica y fetichización de las musulmanas; (b) lícito/ilícito y la capacidad de agencia y protagonismo de estas mujeres; (c) conocimiento religioso y empoderamiento femenino. La investigación nos permite destacar dimensiones de las vivencias de mujeres musulmanas que se diferencian de la posición subordinada a la que están constantemente sometidas.

PALABRAS CLAVE: Sexualidad; Mujeres musulmanas; Decolonialidad; Islam en Brasil.

ABSTRACT: Gender and sexuality studies are prominent topics in current research regarding the Islamic field. There is an incentive to pleasure within religion that contradicts the oppressed and repressed Muslim woman stereotype, as well as the problematic relationship between feminism and religion that many Muslim academics and militants have been trying to deconstruct. Reflections on sexuality in Islam from a decolonial perspective derives from the ethnography conducted by the authors. The article seeks to highlight the practices and meanings that Brazilian Muslim women who reverted to Islam attribute to sexuality, within the following axes: (a) Islamic clothing and the fetishization of Muslim women; (b) licit/illicit and the capacity of agency and protagonism of these women; (c) religious knowledge and women's empowerment. The research shows dimensions of the experiences of Muslim women that differ from the position of subalternity to which they are constantly submitted.

KEYWORDS: Sexuality; Muslim women; Decoloniality; Islam in Brazil. 


\section{Introdução}

Este artigo deriva da dissertação de mestrado ${ }^{1}$ defendida junto ao Departamento de Psicologia da Faculdade de Filosofia Ciências e Letras de Ribeirão Preto (FFCLRP/USP), em que a autora realizou uma etnografia sobre a sexualidade no Islã, dando ênfase às experiências das mulheres muçulmanas. Nossas interlocutoras, longe de proceder de países árabes como se poderia supor, são todas brasileiras de diversos sotaques: Ângela, Tereza, Bruna, Márcia, Cristina, Rita, Sandra, Luciana, Paula, Luana e Marília². Embora já soasse para nós como um campo fértil, em 2015 percebemos que este tema nunca havia sido tratado academicamente no cenário nacional e, mais ainda, constatamos como os(as) muçulmanos(as) vinham sendo negligenciados da literatura psicológica em geral, sendo escassos os estudos junto aos seguidores dessa denominação religiosa ${ }^{3}$. Compartilhamos da posição de Maldonado-Torres (2007) de que "a desqualificação epistêmica se converte em instrumento privilegiado da negação ontológica” (p. 145) e, como aludem Alves e Delmondez (2015), a não-representação e o não-reconhecimento de determinados sujeitos no campo da Psicologia é uma forma de manutenção da opressão e subalternidade que estes sujeitos vivem.

Assim, fizemos uma releitura de Spivak (1988/2010) para indagarmos: pode a mulher muçulmana falar sobre sexo? Incomodada com os equívocos que circulavam sobre a chamada "condição das mulheres no Islã" (El Hajjami, 2008), usualmente atrelada aos estereótipos de uma suposta opressão e repressão que recairia sobre elas, e motivada pelo objetivo de compreender como se dava a experiência da sexualidade para mulheres muçulmanas em consonância com a sua identidade religiosa, a primeira autora foi introduzida em campo islâmico, ao qual a segunda autora já se dedica há mais de duas décadas. Conforme demos andamento à pesquisa, percebemos junto às ainda tão mal conhecidas (Cardeira da Silva, 1997) mulheres muçulmanas brasileiras revertidas ${ }^{4}$ a necessidade de que maior atenção fosse concentrada sobre elas, o que fez com que delimitássemos nossa etnografia junto a estas mulheres. Buscou-se romper a arraigada concepção de que muçulmanas são necessariamente árabes ${ }^{5}$ : o Islã está presente globalmente e cada vez mais coloca novas questões em evidência.

O boom dos estudos de gênero e sexualidade se deu a partir dos anos 1960 e tem se fortalecido ao longo das últimas décadas com o crescimento e impulso dos movimentos sociais e sua inserção participativa na academia. Os eixos são diversos, uma explosão de discursividades: feminilidades, masculinidades, homo/heterossexualidades, saúde e direitos reprodutivos, educação sexual, pornografia e erotismo são alguns deles. No campo das Ciências Humanas, a sexualidade deixou de ser pensada pelo viés organicista e passou a ser encarada como uma construção social, perpassada pela cultura. Neste cenário contemporâneo de recrudescimento de pesquisas em gênero e sexualidade, destacam-se os estudos antropológicos, atentos a como os diferentes povos e comunidades tradicionais concebem essas questões. Na Psicologia, para além dos profícuos estudos psicanalíticos e clínicos, passa a haver uma demanda para que estes tópicos sejam debatidos desde uma perspectiva mais direcionada ao social: um chamado para que se "redescubra" a potencialidade da pesquisa sobre sexualidade através das lentes de outras abordagens (Paiva, 2008).

Não ignorando as dificuldades enfrentadas neste campo cheio de nuances e comedimentos, mas sobressaindo a necessidade de ouvir das próprias mulheres quais eram suas agendas, conversamos com mulheres muçulmanas brasileiras revertidas sobre a temática da sexualidade - embora a etnografia seja mais ampla, dialogar diretamente com elas foi 
crucial para o alargamento da compreensão sobre este assunto. Pretendemos levantar neste artigo alguns pontos de destaque dessa aproximação entre sexualidade e religião: não estamos falando de temas que se opõem ou se distanciam, mas se aproximam na medida em que consideramos a religião como um importante fator para a constituição das subjetividades. Se a atividade sexual "sempre esteve atrelada a regras que variam segundo as sociedades" (Santos \& Ceccarelli, 2010, p. 23), temos as religiões como uma das principais instâncias reguladoras da experiência e do exercício da sexualidade. Sexo e religião entrelaçam-se, ainda que essa relação oscile entre "o secular e o religioso, o sexo e virtude, a religião e a luxúria, o pecado e a santidade, o sexo e a liberação, o sexo e a verdade, o sacrifício e a redenção ..., o prazer e o gênero" (Birman \& Benítez, 2007, p. 9).

Sobre o último par, prazer e gênero, trata-se de ponto nevrálgico não apenas quando associado com a pertença religiosa, seja ao Islã ou a qualquer outra, mas que deve ser problematizado devido à própria estrutura patriarcal da sociedade brasileira. Em sua análise de como a Medicina ocidental moderna enfatizou e legitimou a diferença sexual, Rohden (2001) constatou que as mulheres foram historicamente concebidas pela ideia de que "as características femininas refletiriam a missão passiva que a natureza reservara" a elas (p. 29). Sexualmente, tal "natureza" conduziria à "frigidez feminina" e ao entendimento de que "o prazer da mulher durante o ato sexual não era necessário para a procriação" (p. 30) - discursos que evidentemente serviam ao reforço da "presumida passividade, modéstia e domesticidade” (p. 42) das mulheres. Ainda que em um cenário propício a rupturas e contestações, algumas convenções de gênero persistem pela sustentação de certas dicotomias, como a associação entre masculinidade/atividade e feminilidade/passividade sexual (Simões, França, \& Machado, 2010), bem como seu correlato com dominação/submissão (Simões, 2016).

Estes estigmas e tensionamentos fulguram ao atentarmos para a interseção entre ser mulher e ser muçulmana: como mostraremos nas próximas seções, através de extratos de materiais que circulam na mídia e pelos relatos das interlocutoras, a pertença religiosa dessas mulheres costuma ser equivocadamente associada à insatisfação sexual e a uma relação estritamente ligada à reprodução. Neste artigo, buscaremos evidenciar como a discussão sobre gênero e sexualidade está presente também dentro do Islã e é uma pauta importante das mulheres muçulmanas, o que já nos levou a apontar em ocasiões anteriores que sexo no Islã não é tabu (Paiva \& Barbosa, 2017), mas sim devoção (Barbosa \& Paiva, 2017). A seguir, destacaremos múltiplas esferas da sexualidade que emergiram nos diálogos que estabelecemos com essas mulheres: para além das regras, também a diversidade de práticas e experiências, as variadas formas de exercer e entender o empoderamento feminino, as soluções para lidar com as dificuldades que surgem na temática da sexualidade, as escolhas e negociações que são feitas cotidianamente, entre outras. 


\section{"Pensam que a gente faz sexo de abaya"": a vestimenta islâmica e a fetichização da muçulmana}

Quando se fala em mulheres muçulmanas, o primeiro item que vêm à tona nas discussões diz respeito à vestimenta islâmica. Uma informal pesquisa em um motor de buscas nos devolveu, entre tantos outros resultados ora curiosos, ora inquietantes, a seguinte manchete: "Por baixo da burca: muçulmanas investem em lingeries sensuais de Nova Friburgo" (2012) 7 . O texto afirma: "as longas vestimentas cobrem quase que por completo o corpo das mulheres muçulmanas", mas "entre quatro paredes e debaixo das burcas, as regras caem literalmente por terra". A matéria prossegue: "debaixo das pesadas e sóbrias vestimentas femininas se esconde uma infinidade de cores e formatos". Outra, intitulada "A liberação sexual no Islã" (2009) ${ }^{8}$, embora aponte que "o tabu começa a cair", pois "as mulheres [muçulmanas] estão falando abertamente sobre sexo”, o faz acompanhado de uma imagem recortada de olhos verdes femininos extremamente carregados de maquiagem e delineados sedutores, deixando apenas um pedaço do véu à mostra. Essas matérias, há quase uma década publicadas, são apenas um ponto de partida: ainda hoje seguimos com uma proliferação de artigos cujas chamadas trazem o "por baixo do véu", "por trás do véu", "sob o véu", "o Islã sem véu”, entre outros. Constata-se como a muçulmana é fetichizada sob o clichê do "desvelar-se": o que esconderia por baixo do hijab, da burqa, do niqab?

Paula é a interlocutora que mais percebe como a vestimenta islâmica assume caráter sexualizado: "existe uma tendência a se criar uma imagem que a gente, não sei, de repente pensam que a gente faz sexo de abaya", concepção que compõe este estereótipo colonialista sobre o corpo das muçulmanas. A negativação da diferença do sujeito colonial faz com que ele passe a ser representado pelo estereótipo, fixo e repetitivo, fruto da articulação entre a diferença racial e sexual (Bhabha, 2007): nós sempre saberíamos de antemão que mulheres muçulmanas são oprimidas e reprimidas, sua diferença é sempre negativa e nunca erradicável. O estereótipo é, portanto, "um modo fetichista de representação" (p. 119). A demarcação da diferença sempre fez parte dos projetos coloniais, sendo a sexualidade um de seus elementos centrais - se não o principal. Como aponta McClintock (2010), eram as mulheres a terra a ser "descoberta, penetrada, nomeada, inseminada e, acima de tudo, possuída” (p. 32). Em The Colonial Harem, Alloula (1986) analisou as representações pictóricas feitas pelos franceses acerca das mulheres muçulmanas durante o período em que a Argélia vivia sob a colonização francesa e constatou como era escancarada a obsessão dos homens europeus com o corpo coberto da mulher muçulmana. O incômodo com a inacessibilidade sexual destas mulheres extrapolava uma mera analogia: colonizar implicava se apropriar, também sexualmente, das "exóticas mulheres de véu”, "penetrando o segredo” que estas pareciam esconder (p. XVI).

O corpo fetichizado da mulher muçulmana tem, portanto, origem antiga, profunda, traumática e colonial. A base para essa discussão é dada por Said (1978/1990), em sua obra clássica sobre como o assim chamado "Ocidente" construiu um "Oriente" não com base no que ele realmente é, mas sim nas representações feitas sobre ele. Por muito tempo o "Oriente" foi construído como um paraíso sexual, deleite para sexo licencioso: uma justaposição de haréns, desertos, princesas, véus, dançarinas. Atualmente, tal imagem polarizou-se: imagina-se um "Oriente" retraído, contrário às liberais Europa e América do Norte, visto que é característico ao orientalismo forjar uma "experiência de contraste" 
(p. 14). Narrado por Said, um exemplo deste contraste usado para a sexualização e objetificação da mulher oriental são os relatos do escritor francês Gustave Flaubert sobre seus encontros com Kuchuk Hanem, uma dançarina egípcia famosa na época. Said aponta: "ela nunca falou de si mesma, nunca representou suas emoções, presença ou história. Ele falou por ela e a representou" (p. 17). Ele, o homem, branco, colonizador. Nessa perspectiva orientalista e colonialista, "as mulheres costumam ser criaturas de uma fantasia masculina de poder" (p. 214). Atribui-se a elas uma "sensualidade ilimitada", sendo o véu representado com "um profundo e rico fundo de sexualidade feminina” (p. 189), o que gera uma "associação quase uniforme entre o Oriente e o sexo" (p. 195).

Em nosso diálogo, Marília, casada com um homem muçulmano marroquino, conta que se aproximou da religião devido ao seu forte encantamento com um item cultural árabe (e não religioso), bastante imiscuído em nosso imaginário orientalista: a dança do ventre. Foi por meio da dança e da sensualidade que ela carrega consigo que a imagem do Islã propagou-se em nosso país, fato que é em parte atribuído às telenovelas brasileiras, como a frequentemente lembrada $O$ Clone, exibida entre outubro de 2001 e junho de 2002 na Rede Globo de televisão: se por um lado esta produção reforçou estereótipos, por outro trouxe visibilidade às comunidades árabes-islâmicas, apresentando-as aos brasileiros (Barbosa-Ferreira, 2015). Após a reversão ao Islã, Marília sente fortemente o embate gerado pelas representações da "dançarina exposta" e da "mulher coberta":

A forma de me vestir passou a ser mais recatada, sem exposição do corpo. Parei de usar maquiagem e esmalte nas unhas e estes fatos todos aconteceram antes ainda de adotar o hijab. Para uma pessoa que estudou dança por sete anos, que dançava expondo o corpo... foi como ir do vinho para a água!

Ainda sobre tal contraste, Marília comenta como era curioso andar pelas ruas de algumas cidades marroquinas que conheceu na companhia do seu marido e ver mulheres cobertas entrando em lojas que vendiam roupas sensuais. Na época, ela julgava haver uma contradição no fato de que mulheres muçulmanas consumiam e até mesmo valorizavam estes itens, o que a levou a ficar surpresa com "essa esfera de restringir e permitir", que "andam juntas, lado a lado". Essa suposta ambiguidade atenua-se, do ponto de vista religioso, quando se pensa no público/privado, importante chave para entender a dinâmica das relações de gênero e sexualidade no Islã. Como diz Ângela, fazendo uso de uma frase repetida por muitas mulheres em campo, "a gente não se arruma para fora da casa, a gente se arruma para dentro da casa". Sobre isso, fazemos menção a um trecho da tese de BarbosaFerreira (2007), em que ela questiona uma interlocutora sobre o sentido da dança, atividade com alta conotação sensual, se apenas mulheres poderiam apreciar outras mulheres, ao que a interlocutora retruca que elas dançam para os maridos (p. 47), ou seja, na intimidade do espaço doméstico.

Lamrabet (2014) constata: "é o corpo da mulher muçulmana que parece hoje encarnar o lugar de tensão entre as representações de modernidade e de antimodernidade"(p. 31), ou, em outras palavras, de liberdade e de opressão. O hijab, o véu islâmico, acabou sendo tomado como uma marca visível da suposta repressão sexual das mulheres muçulmanas, ao passo que, para elas, trata-se de devoção a Deus, ou que podemos ler também como um sinal diacrítico que marca sua identidade e pertença como mulher $e$ como muçulmana. 
Na maior parte das vezes, ignora-se que se trata de uma prescrição religiosa: não é um acessório e não deve ser imposto por familiares, mas sim compreendido como um dever religioso. Em campo, são muitos os discursos que circulam sobre o véu: além de um marcador desta identidade, é comum ouvir que ele protege as mulheres, inclusive de assédios, comentários feitos em geral por homens, que muitas discordam. O véu também possui um tom político, segundo o qual o uso do hijab sinalizaria resistência diante das proibições de seu uso: ao escolher usá-lo, ele passaria a representar o orgulho que aquela mulher sente em ser muçulmana.

Apesar de todos esses sentidos, uma cruel realidade se apresenta, como a de Luciana, que demonstrava um profundo sofrimento ${ }^{9}$ por ter retirado sua vestimenta. Após anos desempregada, percebeu que sua dificuldade de recolocação era por conta do hijab. Pesarosa, ela abandona seu uso, apaga as postagens públicas sobre o Islã nas suas redes sociais e rapidamente é admitida em um novo emprego. Entretanto, por "ter que lidar com um público de classe alta”, foi solicitado a ela que alisasse seus cabelos cacheados. Além da intolerância religiosa, o racismo: nunca basta, nunca terminam as múltiplas violências que incidem sobre os corpos das mulheres. A polêmica acerca da vestimenta islâmica é tão forte que leva Adlbi Sibai (2016) a trabalhar a "mulher muçulmana com hijab" como um constructo. Por ser o hijab tratado como incapacitante, a "mulher muçulmana com hijab” é construída como passiva, monolítica, inferior, sexualmente reprimida, símbolo da opressão feminina universal, vítima do sistema patriarcal, impossibilitada de falar e incapacitada para a agência social (p. 34): todas as realidades árabes-islâmicas passam a ser ditadas por essa imagem congelada da "mulher muçulmana com hijab”, o que alimenta e fortalece as agendas coloniais (p. 134).

Há anos estamos assistindo ao debate da proibição das vestimentas islâmicas em determinados ambientes públicos, sobretudo em alguns países da Europa, com o argumento de que o hijab ameaçaria a liberdade. Pergunta-se: de quem? Os "homens brancos procurando salvar as mulheres de pele escura dos homens de pele escura" (Spivak, 2010, p. 115); as "mulheres brancas buscando salvar mulheres cor de café" (Bidaseca, 2011); e as alegações de que "as mulheres muçulmanas precisam de salvação" (Abu-Lughod, 2013) são problemáticas por sugerirem ser necessário resgatar mulheres de suas próprias vidas, de seus próprios contextos. Adotar a postura salvacionista é atuar como colonizador desses corpos: são muitas as violências associadas às presunções que estão sendo feitas sobre a superioridade daquilo para o qual você a está salvando e a inferioridade daquilo do qual ela deve ser salva. As interlocutoras, ao estabelecerem a relação vestimenta-sexualidade de uma forma muito distinta da que circula pelo senso comum, sinalizam que é inaceitável que as muçulmanas sejam desveladas, concreta ou simbolicamente, para então terem sua existência reconhecida. 


\section{“Isso não é haram, então faça”: agência e protagonismo de mulheres muçulmanas}

Em julho de 2017 surge uma publicação que chama a atenção de alguns membros das comunidades islâmicas internacionais: "The Muslimah sex manual": a halal guide to mind blowing sex", um guia sobre sexo halal especialmente dedicado às mulheres muçulmanas. Halal e haram são duas categorias importantes para explorar a temática da sexualidade no Islã: halal é o lícito, permitido; haram é o proibido. Sob o pseudônimo de Umm Muladhat, a autora explica que seu livro é dedicado às mulheres casadas, que vivem o sexo dentro do contexto do casamento, mas que querem experimentar uma gama de experiências com o cônjuge. Ela acrescenta que sublinha o termo halal porque percebia que as mulheres casavam-se sabendo pouco sobre sexo, e o ínfimo que sabiam era sobre o que é considerado proibido, e não todo o resto que é permitido e incentivado.

No Islã os interditos sexuais são poucos: o sexo deve ser feito após o casamento (nikah) e exclusivamente com o cônjuge; as práticas proibidas são basicamente o sexo anal e o sexo durante o período menstrual da mulher. Embora ciente das prescrições, Sandra diz que não lhe agrada o uso do termo haram: em sua opinião, "a religião mostra o caminho e dá as diretrizes", mas "o que é feito entre o casal está só entre eles”. Para ela, existe a clareza de que as normas foram estabelecidas por Allah ${ }^{11}$, mas a seu ver cabe a cada casal o arranjo de seus desejos e a negociação de suas práticas. Sobre isso, é importante apontar que o sexo no Islã não significa direito do homem e dever da mulher, pois um dos objetivos do casamento é justamente o de propiciar a satisfação sexual de uma forma lícita. Existe, portanto, um direito compartilhado por homens e mulheres ao prazer sexual e é Tereza quem faz questão de enunciar que não aceita mais a possibilidade de experienciar um relacionamento em que o sexo seja desprazeroso. Em seu primeiro casamento islâmico, com um muçulmano de um país do oeste africano, enfrentou muitas dificuldades sexuais:

Por causa da cultura dele, ele era muito cheio de não, não e não. Tudo era haram, haram, haram. Ai eu peguei e pedi uma reunião individual com o sheikh ${ }^{12}$ do lugar onde a gente morava, sentei ele na frente do sheikh e fui perguntando detalhes. Falei: sheikh, sexo oral pode? Ele olhou para mim e perguntou: como assim, Tereza? Respondi: sheikh, o senhor tá entendendo o que eu tô perguntando, só por favor me responda na frente dele [marido], pra ele saber o que pode e o que não pode. Ai ele [sheikh], muito envergonhado, olhou para o meu marido e disse: está escrito no Livro uma coisa que não é permitida, que é o sexo anal. Então vocêfaça tudo que não seja isso e que a sua mulher pedir, porque a sua obrigação é dar prazer para a sua mulher.

Após esta conversa com o sheikh, Tereza conta que quando o marido "começava com o haram delè", ela o interrompia e relembrava: "você já ouviu que não é haram, então faça!. Hoje casada com um muçulmano brasileiro revertido, ela relata que antes de oficializar o compromisso disse ao então pretendente que para ela "o sexo é oitenta por cento da relação" e que queria um parceiro para "acompanhá-la em seus desejos", caso contrário seria "melhor ficar sem homem”. Por ser o sexo muito importante em sua vida, Tereza vai em busca da realização de seus desejos e vontades, conciliando-as com o que é estipulado pela sua religião. 
Ângela também faz alusão ao sexo lúdico: "não é todo dia, mas eu ponho uma musiquinha, uns brincões, faço maquiagem, coloco unha postiça ... ele [marido] ama isso". A interlocutora entende sua caracterização como uma performance: "eu sou mais performática do que ele, ele é um bom apreciador". Não só sexo é performance, a religião como um todo também é. Em outra oportunidade, Barbosa-Ferreira (2009) trabalhou com um dos elementos mais performáticos da religião islâmica, que é a salat, a oração. Assim como o ator ensaia para aproximar-se da perfeição, o muçulmano também aprimora seu gestual e molda seu corpo por meio da repetição: os sentidos são refinados através da prática ritual religiosa diária, que contribui para a constituição do corpo islâmico. Ser mulher muçulmana é igualmente uma construção, um processo constante, e a experiência do sexo no casamento será composta pelo aprendizado e aprimoramento das "técnicas do corpo" (Mauss, 1935/2015).

Como mostrado pelas interlocutoras acima, existe uma visão positiva do Islã em relação à experiência da sexualidade, incentivando os prazeres e não apenas a reprodução (como disse o sheikh ao marido de Tereza: "a sua obrigação é dar prazer para a sua mulher"). Apesar disso, Azam (2013) aponta que, na prática, existem diversas dissonâncias entre esses discursos: pouca ênfase é dada ao desejo feminino, ainda relegando a mulher muçulmana a uma posição de passividade tímida, suposto modo de agir de uma esposa virtuosa; e raramente é ressaltado o caráter lúdico e recíproco da relação sexual, dando prioridade à visão do sexo como uma necessidade do homem. Tal assimetria estabelece que o homem é sujeito da sexualidade, enquanto a mulher é objeto dela: uma visão opressora do sexo, que historicamente reproduz a exclusão das mulheres do debate sobre seus próprios desejos (Mernissi, 2002). Essa problemática aparece no relato de Marília, que diz fazer sexo "só para satisfazer meu marido e não porque estou com vontade". A interlocutora conta que a "esfriada no sexo" aconteceu depois que ela engravidou:

Antes dela [do nascimento da filha] eu tinha bastante desejo, sentia vontade. Durante a gravidez as coisas já foram mudando. Já reclamei para a médica, achava que era o anticoncepcional, mas ela me diz que é a rotina de trabalhar, cuidar de criança, da casa. Isso tira a nossa disposição pro sexo, porque [nós mulheres] cansamos.

Marília faz alusão à sobrecarga da mulher. No Islã, homens e mulheres possuem responsabilidades distintas: ao homem é atribuído o sustento da casa e, à mulher, o cuidado. Isso de forma alguma significa que mulheres não podem contribuir financeiramente - Marília, assim como todas as outras interlocutoras de nossa pesquisa, trabalha tanto dentro quanto fora de casa. Da mesma forma, o cuidado com a casa e os filhos não é exclusividade da mulher, do ponto de vista religioso o homem pode (e deve) compartilhar tarefas - fazemos lembrança de um hadith ${ }^{13}$ segundo o qual o profeta Muhammad realizava uma série de tarefas domésticas. Ao falar das exaustivas jornadas de trabalho das mulheres e sua sobrecarga cotidiana, Marília segue trazendo à baila como as questões de gênero atravessam a experiência da sexualidade.

Bruna, que estava em sua segunda gestação durante nossa entrevista, apontou que também vivia um período sexualmente delicado com o marido, muçulmano de origem bengali: ela sentia dores e incômodos devido à gravidez de risco, e ele preocupava-se excessivamente com as finanças do casal, o que, no entendimento de Bruna, estava "impactando diretamente a libido dele". Tal "crise da masculinidade islâmica" (De Sondy, 2013) reforça que também dentro do Islã as concepções de feminilidade e de masculinidade vêm sendo contestadas, o que cede espaço para pensarmos sobre as novas configurações de corpos e desejos (Ozyegin, 2016). 
A questão feminilidade-masculinidade também é elucidada por Cristina. A interlocutora se define: "eu sou muçulmana, brasileira, estudante, trabalhadora, esposa, mãe". Cristina enumera seus múltiplos papéis exercidos cotidianamente e, na ocasião do nosso contato, era ela a responsável pelo sustento financeiro do lar, ao passo que o marido, egípcio, era quem se dedicava mais ativamente ao cuidado com a casa e os filhos, o que inverte a lógica tradicional islâmica. Para ela, a vida de casada está longe de ser "um mundo cor de rosa", mas "é a vida real”: a visão de Cristina sobre a conjugalidade e a sexualidade, bastante realista, difere da idealização muitas vezes feita sobre o casamento com um homem muçulmano, cujos (des)encantos foram estudados por Pasqualin (2018).

Se muitas buscam no muçulmano estrangeiro um “príncipe das Arábias”, Tereza enaltece seu casamento atual - relembramos que ela é a única interlocutora casada com um homem muçulmano brasileiro, também revertido. Ela diz que eles conseguiram unir cultura e religião em "um casamento tupiniquim, com o calor dos trópicos". Tereza traz uma discussão importante sobre o marcador étnico-racial, bastante presente no discurso das mulheres. Frequentemente tenta-se desprivilegiar a mulher muçulmana brasileira por um uso pervertido desse marcador em associação a gênero e religião, o que faz persistir o estereótipo da "superioridade árabe" ou, como ouvimos em campo, dos "muçulmanos originais", que seriam os nascidos em famílias muçulmanas, uma visão depreciativa que recai sobre revertidos(as). Aqui, Tereza faz outro uso: alia nacionalidade brasileira e erotismo, com o intuito de valorizar sua escolha por um marido brasileiro, e não estrangeiro de origem árabe, como é o caso da maioria. Entretanto, vale apontar como gênero e raça vêm sendo articulados para criar o imaginário do "sexo tropical" (Piscitelli, 1996), que coloca as brasileiras como possuidoras de uma sensualidade inata, nativa, culminando em uma posição de sexualização e objetificação.

Todos esses dados nos ajudam a pensar como as identidades estão sendo produzidas por essas mulheres dentro da comunidade. Seja abertamente como Tereza, ou sutilmente como Sandra, quando nos dá um exemplo metafórico bastante elucidativo - "se você deixa o fogão aberto aos finais de semana, o marido entende que você vai fazer comida, se você deixa fechado fica subentendido que ele pode pedir uma pizza... tudo está nas mãos da mulher" as mulheres dão o gancho para pensarmos como estão contrariando a ideia de que os homens estão no comando. As regras islâmicas sobre sexualidade são usualmente consideradas de fácil entendimento, o que faz com que a sexualidade no Islã pareça à primeira vista um assunto encerrado em si mesmo. Contudo, como as mulheres apontam, seus intercruzamentos são complexos. As interlocutoras extrapolam a polarização halal/haram, trazendo em seus relatos suas facilidades e dificuldades com a sexualidade, procurando formas de ressignificar o sexo e buscar sua satisfação pessoal, sem desconsiderar a sua pertença religiosa. Mesmo que às vezes tomem para si partículas dos discursos patriarcais dominantes, as mulheres citadas posicionam-se como sujeitos desejantes, assumindo seu protagonismo, ou sinalizando a vontade de sair das margens rumo a essa posição de centralidade. 


\section{“Se o profeta Muhammad falou, por que não podemos falar?”: conhecimento religioso e empoderamento feminino}

Um tópico emergente das narrativas das mulheres, considerado como importante para a tomada de consciência acerca do corpo e do direito a um sexo prazeroso, é justamente o conhecimento sobre a própria religião. Cristina fala que sua visão crítica só veio quando ela começou a estudar mais o Islã, ou seja, o empoderamento vem também pela via do conhecimento. Uma das questões que acompanhava nossa pesquisa desde o início era por que ainda haveria dificuldade na transmissão de conhecimento sobre sexualidade, visto que a religião em seus primórdios tratava o assunto de forma aberta e direta. Diz-se que o próprio profeta Muhammad estimulava muçulmanos e muçulmanas a fazerem questões sobre todos os assuntos, não deixando "que a timidez fosse um impedimento para aprender a religião" (notas do caderno de campo). Luana, recém-revertida e cheia de dúvidas, queria conversar com outras muçulmanas sobre sexo, mas achou melhor esperar que seu casamento fosse oficializado, para evitar julgamentos sobre o motivo de "querer saber demais sobre certas coisas". Uma das participantes da pesquisa de Mossuz-Lavau (2005) explica: "nós, os muçulmanos, ficamos virgens até o casamento, então não se fala dessas coisas" (p. 381). Como a vida sexual não é concebida fora do casamento, talvez resida neste ponto uma dificuldade em ofertar educação sexual islâmica, ou ao menos dialogar sobre o tema.

Luciana também evidencia que são numerosas as dificuldades que uma recém-revertida enfrenta em matéria de sexualidade, principalmente por ser a virgindade a principal fronteira estabelecida. Importante ressaltar que não apenas as mulheres muçulmanas devem se casar virgens: o preceito é o mesmo para os homens muçulmanos. No entanto, Luciana diz ter ficado espantada com isso, pois "acreditava que somente as mulheres eram educadas dessa forma”. Ela diz ter visitado o Líbano, país de origem do marido, e ter se surpreendido ao ver "rapazes de vinte anos que nunca nem beijaram na boca" e "homens que evitam nos olhar nos olhos, pois consideram isso uma falta de respeito com a mulher". A questão de "baixar o olhar" é parte de dois versículos (Alcorão, 24: 30-31) que descrevem o comportamento ideal para que tanto homens quanto mulheres previnam qualquer contato íntimo-sexual ilícito: como exposto, não apenas o sexo é proibido antes do casamento, mas qualquer contato físico com o sexo ${ }^{14}$ oposto. Apesar disso, Luciana entendia que tais regulações seriam exclusivas às mulheres: alude-se a uma dupla moral, que é permissiva e flexível com os homens, mas cobra das mulheres uma "conduta moral e sexual retilíneas" (Moutinho, 2004, p. 67), visão que a interlocutora reproduz, ainda que sem se dar conta.

Sandra diz que foi dentro do Islã que sanou suas dúvidas sobre sexualidade, pois antes da reversão nunca havia tido quem a instruísse adequadamente: a mãe, católica, "dizia que o órgão sexual masculino era do tamanho de uma cobra, que entrava na gente e saia pela boca ... ela sempre nos colocava muito medo, mas sei que era com boa intenção”. De acordo com Foucault (1976/2015), fala-se muito sobre sexo, mas "valorizando-o como segredo" (p. 36): é estabelecido um silenciamento, ou uma excessiva discrição para falar do assunto, "entre pais e filhos, educadores e alunos, patrões e serviçais" (p. 46). Na seção anterior mostramos como Tereza quebrou o silêncio, procurando o sheikh para esclarecer as dúvidas que o marido tinha sobre sexo no Islã. O sheikh é a figura entendida como capaz de legitimar todo tipo de conhecimento, também sobre sexualidade. Isso fica explícito na fala de Rita, bastante reservada, quando dizia ser "mais vantajoso" que conversássemos com o sheikh e não com ela, "porque ele é que vai saber dar a explicação correta 
[sobre sexualidade no Islã]”. Rita se sentia como que desautorizada a dar seu ponto de vista sobre o assunto, e não entendia como a experiência dela poderia ser importante e legítima para nós.

A falta de informação adequada pode trazer confusões para algumas mulheres. Quando conversávamos sobre o sexo oral, Luciana disse ter parado com esta prática por ter recebido a orientação de que "não se deve colocar a boca que se louva a Allah em um órgão sexual". A resposta nos faz pensar como os discursos circulam e são propagados na comunidade: do ponto de vista islâmico, a prática do sexo oral é considerada aceitável e não proibida, mas basta uma breve pesquisa para chegarmos até inúmeros websites que apontam para essa mesma informação distorcida que Luciana comenta ter recebido. Em conversa particular com o sheikh Mohamad Bukai ${ }^{15}$, ele enfatizou a importância de se estudar a sexualidade na religião. O sheikh comenta que raramente alguém o procura para falar do assunto, mas questiona: "se o Profeta Muhammad falou [sobre sexo], por que nós não podemos falar?". Para Rubin (1975/2017), não transmitir conhecimento às mulheres é claramente uma forma de oprimi-las (p. 15). Neste panorama, a fala do sheikh assume importância ainda maior por ele, autoridade religiosa, estimular as muçulmanas nesta busca. A demanda das mulheres muçulmanas pelo conhecimento não é contra o Islã, mas sim para ele e por ele (Ali, 2012, p. 16): "para que sua mensagem original seja recuperada".

\section{“Temos que derrubar esse tabu da cabeça das pessoas": considerações finais}

O processo de decolonizar as formas de enxergar as mulheres muçulmanas perpassa várias categorias de entendimento, como raça, classe e gênero (Bouteldja, 2016). Entendemos a decolonialidade como contraposição à colonialidade: tal qual os(as) autores(as) denominados(as) como decoloniais costumam expor, mesmo com o fim da colonização formal, a colonialidade permanece e ainda vigora sobre existências, corpos, poderes e saberes. Por sermos pesquisadoras brasileiras, conduzindo uma pesquisa com mulheres muçulmanas também brasileiras, acreditamos que o uso de decolonialidade abarca esse "lugar de enunciação" a partir das "influências corpo-políticas e geopolíticas" (Bernardino-Costa, Maldonado-Torres \& Grosfoguel, 2019, p. 15).

Ao longo do artigo, tentamos evidenciar como a sedimentação da assim chamada “condição das mulheres no Islã”, calcada no estereótipo da opressão/repressão que é, por sua vez, diretamente relacionado a gênero/sexualidade, é resultado de um pensamento que tem origens coloniais e segue marcado pela colonialidade, que barra ou até nega as expressões de agência das muçulmanas. É preciso haver uma abertura à diversidade epistêmica, que contemple outras experiências e saberes que não os hegemônicos: trata-se, portanto, de buscar uma "afirmação da existência" por meio do conhecimento "daqueles que foram apagados, invisibilizados e negados pela colonialidade" (BernardinoCosta, Maldonado-Torres \& Grosfoguel, 2019, p. 16) - aqui, as mulheres muçulmanas brasileiras revertidas ao Islã.

Precisamos, portanto, abandonar o "feminismo sinhá" (Barbosa, 2019): faz-se necessário compreender a autonomia dessas mulheres e suas práticas para sairmos do lugar de colonizador do corpo e dos desejos do outro. Não nos cabe falar por essas mulheres, mas falar com, pois o fator por, as colocaria no mesmo lugar de opressão que tanto criticamos. 
Consideramos a sexualidade uma das tantas narrativas das mulheres pelas quais se engendra o modo de percepção de seus corpos, desejos e prazeres, que são regulados pela religião, mas também pela cultura: sabemos que os sentidos se alteram dependendo se são mulheres muçulmanas brasileiras, árabes, africanas, asiáticas. Por isso, para esta finalização, cabe-nos trazer as considerações finais ponderadas pelas próprias interlocutoras.

Márcia conclui: "somos mulheres normais, com necessidades normais e temos que derrubar esse tabu da cabeça das pessoas". Em outras palavras, ela está apontando que somos todas mulheres. Interpretamos esse alerta emitido por ela como um lembrete para não tratarmos as mulheres como uma categoria universal, homogênea; mas também ter cuidado para, ao destacar diferenças, não reforçar estereótipos que seguiriam subalternizando essas mulheres, o oposto do que elas precisam.

Paula retoma as categorias halal/haram para afirmar que o sexo, seja no Brasil, no Oriente Médio ou em qualquer outro país/região, sempre terá camadas de significado:

Você sempre vai achar alguém que tenha um comportamento que talvez se você falasse ai, é da sociedade brasileira cristã, você não ia achar muito diferente. Mas se eu te falo que acontece aqui [no Egito, país predominantemente muçulmano], você fala: nossa, tem certeza que isso acontece mesmo? Pode até não ser uma coisa muito comum, mas você vai achar. Sempre vai achar, de tudo, em qualquer lugar... porque eu acho que todas essas coisas são estupidamente humanas.

Parece óbvio, mas nem sempre é, que as mulheres muçulmanas são estupidamente humanas e, por conseguinte, o sexo é uma questão estupidamente humana. Torna-se urgente considerar as demandas e os significados que essas mulheres muçulmanas revertidas conferem às suas experiências, cerne deste artigo. Ainda assim, a fala de Paula põe em cheque a ideia de que as mulheres muçulmanas possuem experiências "exóticas", opostas ou extremamente diferentes das demais mulheres.

É impossível encerrar as questões sobre este tema tão amplo, mas foi possível levantá-las nesse exercício de abordar a sexualidade no Islã. Afinal, entendemos a crítica decolonial como contínua, um projeto ainda no horizonte, o qual vislumbra-se alcançar o próprio título escolhido para este manuscrito está flexionado no gerúndio (decolonizando), como indicativo de algo que está em andamento, uma possibilidade de fazer avançar a discussão. Aqui foram tratados os conteúdos que faziam parte da realidade das mulheres com quem conversamos: se algum tema não foi exposto é porque não foi considerado como relevante por elas e, portanto, não configuram como dados da pesquisa. Foi possível delinear que interditos, estereótipos e dificuldades moldam a experiência do sexo mas, para as interlocutoras aqui citadas, mais do que fechar uma questão, isso será motivo para abrir a reflexão e ser ponto de partida para novas possibilidades e formas sutis de resistência. Às mulheres muçulmanas é permitido experimentar - e falar sobre - o sexo, que definitivamente faz parte da conduta islâmica. 


\section{Notas}

1 Paiva, C. M. (2018). As mulheres, os perfumes e as preces: um olhar simbólico sobre a sexualidade no Islã. Dissertação de Mestrado, Programa de Pós-graduação em Filosofia, Ciências e Letras de Ribeirão Preto, Universidade de São Paulo, Ribeirão Preto. Pesquisa financiada pela Fundação de Amparo à Pesquisa do Estado de São Paulo (FAPESP) Processo nº 2015/26295-2.

2 Todos os nomes das interlocutoras são fictícios.

3 O GRACIAS (Grupo de Antropologia em Contextos Islâmicos e Árabes), sediado no Departamento de Psicologia da Faculdade de Filosofia, Ciências e Letras de Ribeirão Preto (FFCLRP/USP) e coordenado pela Prof ${ }^{a}$ Dr $^{a}$ Francirosy Campos Barbosa, é o primeiro a trabalhar com a interface Antropologia-Psicologia-Islã no meio acadêmico brasileiro. No país, os estudos iniciais se debruçaram sobre o mapeamento das comunidades islâmicas, sua formação e construção de suas identidades. Apenas mais recentemente, tendo suprido parte dessas questões, é que novos pesquisadores podem ampliar sua atuação para temáticas mais específicas, como a sexualidade aqui abordada.

4. Revertido(a)é um termo nativo: segundo a crença islâmica, todos os seres humanos nascem muçulmanos e, quando professam o seu testemunho de fé, retornam à religião da qual tinham se afastado. Damos preferência a estes termos, em detrimento de conversão/convertidos. Não há número preciso sobre muçulmanos no Brasil, mas Pinto (2010), baseado em sua experiência etnográfica, estima que seja da ordem de 100-300 mil.

$5 \quad$ Os árabes constituem apenas um quinto da população islâmica mundial. No Brasil, a presença islâmica é geralmente pensada a partir da imigração árabe, especialmente de sírios, libaneses e palestinos. Entretanto, mais recentemente têm-se recuperado a história dos malês, muçulmanos africanos escravizados que compuseram as primeiras comunidades islâmicas em nosso país, como mostra o documentário "Allah, Oxalá: na trilha Malê" (Barbosa, 2015).

6 Abaya, hijab, burqa e niqab são algumas variedades de vestimenta islâmica. A abaya é um longo vestido negro que se estende até os pés. O hijab cobre cabelos e pescoço, deixando o rosto à mostra. $\mathrm{O}$ niqab cobre a face das mulheres, exceto por uma abertura na altura dos olhos. A burqa, além da cobertura de todo o corpo e face, cobre também os olhos.

7 https://oglobo.globo.com/rio/bairros/por-baixo-da-burca-muculmanas-investem-em-lingeries-sensuais-de-nova-friburgo-4446672 
9 Inúmeras adversidades se apresentam para as muçulmanas revertidas, causando-lhes muito sofrimento. Tais questões serão melhor exploradas pela autora em sua pesquisa de doutorado sobre saúde mental em comunidades islâmicas brasileiras (FFCLRP/USP, em andamento).

10 https://themuslimahsexguide.com/

11 Allah é a palavra árabe para Deus.

12 O sheikh é uma autoridade em assuntos islâmicos e referência para a comunidade.

13 Os hadices são os ditos e feitos do Profeta Muhammad, nos quais os muçulmanos sunitas se espelham para moldar o seu próprio comportamento. Esclarecemos que usamos Muhammad e não Maomé, nomeação considerada pelos muçulmanos como desrespeitosa e pejorativa.

14. Por ser uma menção alcorânica, assume-se o uso de "sexo" e não "gênero" pela primazia dada nesta fonte ao sentido biologizante do termo.

15 O sheikh Bukai, sírio que está no Brasil desde 2006, é atualmente sheikh titular na Mesquita Brasil. Fundada em 1929, é a mesquita mais antiga do Brasil e de toda a América Latina.

\section{Referências}

Abu-Lughod, L. (2013). Do Muslim women need saving? Harvard University Press.

Adllbi Sibai, S. (2016). La cárcel del feminismo: hacia um pensamiento islámico decolonial. Akal.

Alcorão. (2009). O significado dos versículos do Alcorão Sagrado com comentários. Marsam Editora Jornalística.

Ali, Z. (2012). Feminismes islamiques. La Fabrique éditions.

Alloula, M. (1986). The colonial harem. University of Minnesota Press.

Alves, C. B. \& Delmondez, P. (2015). Contribuições do pensamento decolonial à psicologia política. Revista Psicologia Política, 15(34), 647-661.

Azam, H. (2013). Sex, marriage and eroticism in contemporary Islamic advice literature.

Journal of Middle East Women's Studies, 9(1), 54-80.

Barbosa-Ferreira, F. C. (2007). Entre arabescos, luas e tâmaras: performances islâmicas em São Paulo. Tese de Doutorado, Programa de Pós-graduação em Filosofia, Letras e Ciências Humanas, Universidade de São Paulo, São Paulo.

Barbosa-Ferreira, F. C. (2009). Teatralização do sagrado islâmico: a palavra, a voz e o gesto. Religião Ẽ Sociedade, 29(1), 95-125. 
Barbosa-Ferreira, F. C. (2015). Telenovela e Islã: dos estereótipos à visibilidade. Horizonte, $13(38), 771-802$.

Barbosa, F. C. (2019, 08 de março). Mulheres muçulmanas importam - uma escrita contra o feminismo Sinhá ou sobre feministas e 'halfies'. ICArabe. Recuperado de https://icarabe.org/ $\underline{\text { node } / 3565}$

Barbosa, F. C. \& Paiva, C. M. (2017). Sexo/prazer no Islam é devoção. Religião \&̊ Sociedade, $37(3), 198-223$.

Bernardino-Costa, J., Maldonado-Torres, N., \& Grosfoguel, R. (2019). Introdução: Decolonialidade e pensamento afrodiaspórico. In Decolonialidade e pensamento afrodiaspórico (pp. 9-26). Autêntica.

Bhabha, H. (2007). O local da cultura. UFMG.

Bidaseca, K. (2011). "Mujeres blancas buscando salvar a mujeres color café": desigualdad, colonialismo jurídico y feminismo postcolonial. Andamios, 8(17), 61-89.

Birman, P. \& Benítez, M. E. D. (2017). Editorial. Religião E̊ Sociedade, 37(1), 9-13.

Bouteldja, H. (2016). Raça, classe e gênero: uma nova divindade de três cabeças. Cadernos de Gênero e Diversidade, 2(2), 5-9.

Cardeira da Silva, M. (1997). O Islão plástico: transformações da intimidade em contexto popular marroquino. Etnográfica, 1(1), 57-72.

De Sondy, A. (2013). The crisis of Islamic masculinities. Bloomsbury.

El Hajjami, A. (2008). A condição das mulheres no Islã: a questão da igualdade. Cadernos Pagu, 30, 107-120.

Foucault, M. (2015). História da sexualidade 1: a vontade de saber. Paz e Terra. (Original publicado em 1976)

Lamrabet, A. (2014). El velo (El Hiyab) de las mujeres musulmanas: entre la ideología colonialista y el discurso islámico: una visión decolonial. Tabula Rasa, 21, 31-46.

Maldonado-Torres, N. (2007). Sobre la colonialidad del ser: contribuciones al desarrollo de un concepto. In S. Castro-Gomez, \& R. Grosfoguel (Orgs.), El giro decolonial: reflexiones para una diversidad epistémica más allá del capitalismo global (pp. 127-167). Siglo del Hombre Editores.

Mauss, M. (2015). Sociologia e antropologia. Cosac Naify. (Original publicado em 1935)

McClintock, A. (2010). Couro imperial: raça, gênero e sexualidade no embate colonial. Editora da Unicamp.

Mernissi, F. (2002). El harén político: el Profeta y las mujeres. Ediciones del Oriente y del Mediterráneo.

Mossuz-Lavau, J. (2005), Sexualidade e religião: o caso das mulheres muçulmanas na França. Revista Estudos Feministas, 13(2), 377-386.

Moutinho, L. (2004). "Raça", sexualidade e gênero na construção da identidade nacional: uma comparação entre Brasil e África do Sul. Cadernos Pagu, 23, 55-88.

Ozyegin, G. (Ed.). (2016). Gender and sexuality in Muslim cultures. Routledge.

Paiva, V. (2008). A psicologia redescobrirá a sexualidade? Psicologia em Estudo, 13(4), 641-651. 
Paiva, C. M. \& Barbosa, F. C. (2017). Sexo no Islã não é tabu: desejos, prazeres e práticas das mulheres muçulmanas. Revista Reflexão, 42(1), 113-124.

Pasqualin, F. A. (2018). O (des)encanto do casamento intercultural: brasileiras casadas com muçulmanos estrangeiros. Tese de Doutorado, Programa de Pós-graduação em Filosofia, Ciências e Letras de Ribeirão Preto, Universidade de São Paulo, Ribeirão Preto/SP.

Pinto, P. H. R. (2010). Islã e civilização: uma abordagem antropológica. Editora Santuário.

Piscitelli, A. (1996). Sexo tropical: comentários sobre gênero e raça em alguns tex tos da mídia brasileira. Cadernos Pagu, 6(7), 9-34.

Rohden, F. (2001). Uma ciência da diferença: sexo e gênero na medicina da mulher. Editora Fiocruz.

Rubin, G. (2017). Políticas do sexo. Ubu. (Original publicado em 1975)

Said, E. (1990). Orientalismo: o oriente como invenção do ocidente. Companhia das Letras. (Original publicado em 1978)

Santos, A. B. R \& Ceccarelli, P. R. (2010). Psicanálise e moral sexual. Reverso, 32(59), 23-30.

Simões, J. A. (2016). O Brasil é um paraíso sexual - para quem? Cadernos Pagu, 47, e164715.

Simões, J. A., França, I. L., \& Machado, M. (2010). Jeitos de corpo: cor/raça, gênero, sexualidade e sociabilidade juvenil no centro de São Paulo. Cadernos Pagu, 35, 37-78.

Spivak, G. C. (2010). Pode o subalterno falar? Editora UFMG. (Original publicado em 1988) 
CAMILA MOTTA PAIVA

https://orcid.org/0000-0002-1959-182X

Psicóloga, doutoranda em Psicologia na FFCLRP/USP.

E-mail: camilapaiva@,usp.br

\section{FRANCIROSY CAMPOS BARBOSA}

https://orcid.org/0000-0003-0064-5995

Antropóloga, docente no Departamento de Psicologia da FFCLRP/USP.

Coordenadora do GRACIAS - Grupo de Antropologia em Contextos

Islâmicos e Árabes.

E-mail: franci@fffclrp.usp.br

\begin{tabular}{|c|c|}
\hline Histórico & $\begin{array}{l}\text { Sulbmissão: 29/06/2020 } \\
\text { Revisão: 21/08/2020 } \\
\text { Aceite: 27/08/2020 }\end{array}$ \\
\hline $\begin{array}{l}\text { Contribuição } \\
\text { dos autores }\end{array}$ & $\begin{array}{l}\text { Concepção: C.M.P. } \\
\text { Colleta de dados: C.M.P. } \\
\text { Análise de dados: C.M.P. } \\
\text { Elaboração do manuscrito: C.M.P.; F.C.B. } \\
\text { Revisões críticas de conteúdo intelectual importante: F.C.B. } \\
\text { Aprovação final do manuscrito: F.C.B. }\end{array}$ \\
\hline Financiamento & $\begin{array}{l}\text { Bolsa de Mestrado da Fundação de Amparo à Pesquisa do Estado de São } \\
\text { Paulo (FAPESP) - Processo nº } 2015 / 26295-2 .\end{array}$ \\
\hline $\begin{array}{l}\text { Aprovação, ética } \\
\text { e consentimento }\end{array}$ & $\begin{array}{l}\text { O estudo foi aprovado pelo Comitê de Ética em Pesquisa da Faculdade } \\
\text { de Filosofia, Ciências e Letras de Ribeirão Preto (CEP-FFCLRP/USP). }\end{array}$ \\
\hline
\end{tabular}

